\title{
PŘEKLADATELSKÝ PROJEKT „BERTHA VON SUTTNER: DIE WAFFEN NIEDER!"
}

\author{
VĚRA KLOUDOVÁ, PETRA MRAČKOVÁ VAVROUŠOVÁ
}

\begin{abstract}
Translation project "Bertha von Suttner: Die Waffen nieder?"

Translator training has been increasingly relying on simulations of reallife professional practice. One way of bringing learning closer to authentic professional experience is by introducing project-based instruction. The aim of this paper is to present a project conducted in an optional literary translation seminar at the Institute of Translation Studies (Charles University, Faculty of Arts) in the summer semester of the 2018/2019 academic year. Providing students with an opportunity to engage in an authentic translation assignment, the project was a collaborative translation of Bertha von Suttner's Die Waffen nieder! (Lay Down Your Arms!) from German into Czech under the supervision of two Czech university teachers. During the opening session, a work schedule was drawn up, covering all the stages of translation and editing. Later, groups of students worked on individual chapters, consulting across the teams and with the teachers, both in person and through online shared documents, which is also where the editing took place. The students worked independently on authentic tasks in a real-life context, with the teachers acting as facilitators. The principles of cooperative learning were applied to the project as sharing, collaborating and mutual support were part of all the stages of the translation. The participants were administered a questionnaire to explore the learners' attitudes and feelings regarding project-based learning in translator training with a view to identifying the possibilities and limits of this type of learning experience compared with conventional forms of instruction. The latter part of the paper will comment on the most interesting student responses.
\end{abstract}

Keywords: Bertha von Suttner; Die Waffen nieder!; collaborative translation; project-based learning; translator training

\section{Úvod}

Vysokoškolská příprava budoucích profesionálních překladatelů se dnes v maximální možné míře snaží napodobovat reálnou praxi překladatelské profese. Jedním ze způsobů, jak tohoto cíle dosáhnout, je využívat v didaktice překladu tzv. projektovou výuku. Díky 
laskavé nabídce české nevládní organizace PragueVision - Institut pro udržitelnou bezpečnost se podařilo tento úmysl naplnit, a to $\mathrm{v}$ rámci (povinně) volitelného překladatelského semináře zaměřeného na překlad literárního textu vyučovaného v pražském Ústavu translatologie Filozofické fakulty Univerzity Karlovy v letním semestru akademického roku 2018/2019, jehož záměrem bylo umožnit studentům podílet se na reálné překladatelské zakázce. Jejím cílem bylo nově do češtiny přeložit dílo Die Waffen nieder! (1889) z pera autorky Berthy von Suttner. První, v současné době už silně zastarávající český překlad (srov. Levý 1998, 78) totiž vyšel pod názvem Odzbrojte! už v roce 1896, překladu se tehdy zhostila Vlasta Pittnerová. Kromě značně archaického jazyka vykazovala první česká verze i nedostatky po obsahové stránce, a tudíž bylo záhodno toto význačné dílo představit současnému českému čtenáři v adekvátní a pro něj přijatelné podobě. Tento počin byl zároveň př́ležitostí, jak zvýšit povědomí o ženě, která byla významnou osobností mírového hnutí přelomu 19. a 20. století.

\section{Bertha von Suttner - život a dílo}

Bertha von Suttner se narodila v roce 1843 v Praze jako hraběnka Kinská, byla tedy českého původu - přesto není u nás známá tolik jako v sousedním Rakousku. Vyrůstala v Brně, žila ve Vídni, krátce také v Paříži, kde pracovala jako sekretářka u Alfréda Nobela, se kterým navázala dlouholeté přátelství. S manželem Arthurem von Suttnerem, za kterého se tajně provdala i přes nesouhlas jeho rodiny, pobývala v Gruzii, kde zažila rusko-tureckou válku. Tento válečný konflikt a jím způsobené lidské utrpení na ni zapůsobily natolik, že se stala radikální a velice aktivní pacifistkou.

V roce 1885, po usmíření s rodinou, se manželé Suttnerovi vrátili do Rakouska, kde Bertha napsala většinu svých děl, především protiválečných studií. Inspirovala se reportážemi i prací vojenských lékařů, věnovala se publicistické činnosti. Na základě její usilovné práce vznikl román Die Waffen nieder! (1889), který se i přes počáteční rozpaky způsobené velkou mírou v něm obsažených radikálních antimilitaristických myšlenek stal velmi oblíbeným a byl v nadcházejících letech přeložen do řady jazyků. Toto dílo zcela realisticky popisuje katastrofální důsledky válečných bitev, bez příkras líčí utrpení vojáků na frontě a ukazuje dopady války na celou společnost. Prostřednictvím hlavní postavy románu, rakouské šlechtičny Marty von Tilling, která zažije hned několik osudových ran způsobených zbrojením a válkami, je tak zpochybněna tehdejší víra v ušlechtilost války i v samotné vojenské poslání.

Bertha von Suttner se po celý svůj další život veřejně angažovala. Účastnila se prvních mírových kongresů a věnovala se veřejné činnosti spojené s šířením idejí humanismu a varováním před válečnými konflikty - od roku 1892 vydávala protiválečný časopis, stála u zrodu několika mírových spolků. Za svou činnost byla v roce 1905 jako první žena oceněna Nobelovou cenou za mír. V září 1914 se měl ve Vídni konat mírový kongres, který Bertha von Suttner připravovala i přes pokročilé stádium svého onemocnění. Zemřela však v červnu 1914, tedy nedlouho před vypuknutím dosud největšího válečného konfliktu - první světové války. 


\section{Projektová výuka}

Než se zaměříme na průběh a př́nosy či úskalí našeho konkrétního překladatelského úkolu, popišeme obecně znaky a pozitiva projektové výuky. Osvojování učiva v současné době vnímáme jako akt individuálního poznávání, v jehož centru stojí sám student a jeho sociální vztahy s vrstevníky, nikoli pouze s učitelem, takže tradiční transmisivní př́stup a frontální uspořádání výuky - i ve výuce překladu - ustupuje, př́ípadně se kombinuje s jinými způsoby vedení hodin. Do popředí se dostávají moderní organizační formy vyučování, jako je např. projektová výuka, kdy je učební proces předán do rukou učícího se subjektu. Projektové vyučování se totiž orientuje především na zkušenosti žáka a jeho cílem je vyřešit nějaký teoretický či praktický problém, a to na základně aktivní činnosti žáků - tato společná práce přispívá $\mathrm{k}$ jejich rozvoji, nebot jde o činnost, se kterou se student ztotožní, kterou prožívá (Skalková 2007, 234). Projektová výuka, včetně práce ve skupině, o které pojednáme podrobněji níže, vychází z konstruktivismu (srov. Rohlíková - Vejvodová 2012, 101-150). „Konstruktivistické přístupy k učení kladou důraz na sociální dimenzi učení - na význam společného hledání, objevování a konstruování poznání na základě vlastní činnosti, komunikace, interakce a spolupráce“ (Rohlíková Vejvodová 2012,137). Učitel vystupuje v roli facilitátora a studenti samostatně plní autentické úkoly. $\mathrm{V}$ didaktice překladu tedy tento způsob výuky umožňuje simulovat reálnou praxi př̀kladatelské profese a nabízí tak budoucím profesionálním překladatelům tu nejlepší formální přípravu na výkon svého zaměstnání. Cílem projektově zaměřeného překladatelského semináře je překonat jistou odtrženost od životní/pracovní praxe, čímž umožňuje zvyšovat kvalitu učení.

Skalková $(2007,235)$ navrhuje následující schéma, jak postupovat při projektové výuce: Na počátku studenti stojí před reálně zadaným úkolem. Nejprve je potřeba s nimi prodiskutovat plán řešení (formulovat a zpřesnit otázky, kterými se budou skupiny zabývat). Těchto diskuzí se účastní všichni studenti, mají prostor k vyjádření vlastních názorů, na které ostatní reagují. Nakonec vznikne plán (kdo bude mít jaké úkoly), který určuje, jak se bude postupovat při řešení zadané úlohy. $V$ závěrečné fázi projektu jsou představeny výsledky a je celkově zhodnocena práce na projektu.

Projektová výuka pomáhá rozvíjet hned několik dovedností (srov. Rohlíková - Vejvodová 2012, 138), nejprve jde o dovednosti analytické, nebot student musí nejdříve identifikovat daný problém, vyhodnotit veškeré poskytnuté informace a údaje a určit si priority. S tím souvisí dovednosti rozhodovací, kdy je nutné hledat nejrůznější alternativy a určit si nejvhodnějši ř řšení a plán, jak jej dosáhnout. Aplikační dovednosti pak souvisejí s užitím teorií, metod a technik, které si studenti již osvojili v rámci dosavadního učebního procesu. S diskuzí, které se budeme věnovat na následujících rádcích, pak souvisí dovednosti komunikační a interpersonální i sociální, tj. studenti většinou nejprve daný úkol řeší individuálně, poté $\mathrm{v}$ menších týmech, $\mathrm{v}$ závěru projektu pak celá skupina studentů, takže studenti mezi sebou musí nutně komunikovat a užívat také tzv. soft skills, a to $\mathrm{k}$ řešení př́padných problémů či konfliktů, hledání společného řešení, výměně názorů s druhými či ke spolupráci s dalšími jedinci. Studenti se rovněž musí naučit, jak účinně využívat čas, čímž zdokonalují také své dovednosti potřebné pro time management. A v neposlední řadě mohou uplatnit i své kreativní dovednosti, nebot porovnávají své návrhy s myšlenkami ostatních kolegů, a díky různorodým myšlenkovým pochodům 
celé skupiny pak vzniká výsledné společné řešení, které dosahuje vyšší úrovně a kvality než jednotlivé dílčí návrhy.

Jedním z hlavních znaků projektové výuky je práce ve skupině. „Skupinovým vyučováním chápeme takovou organizační formu, kdy se vytvářejí malé skupiny studentů (3-5členné), které spolupracují při řešení společného úkolu“ (Skalková 1999 in Rohlíková - Vejvodová 2012,49). Často si pedagog klade otázku, podle jakého „klíče“ rozdělit studenty do skupin? Kritéria výběru se různí, důležité je např. hledisko výkonu, sociálních vztahů, zájmu nebo náhody (Rohlíková - Vejvodová 2012, 50).

Významnou roli v projektovém úkolu hraje také diskuze, jež „[...] je vzájemným rozhovorem mezi všemi členy skupiny, v němž jde o vyjasnění stanovené problematiky.“ (Skalková 2007, 191) Předpokládá se předchozí příprava studentů, účastníci diskuze se snaží analyzovat daný problém, osvětlit jej, vyřešit jej. Skalková $(2007,192)$ spatřuje pozitiva diskuze v následujících bodech: Prostřednictvím diskuze mohou studenti rozvíjet své komunikační dovednosti, získávat nové poznatky, participace v diskuzi jim umožňuje přemýšlet o názorech svých i o názorech spolužáků, učí se soustředěně poslouchat a vyslechnout druhého, pohotově reagovat na stanoviska ostatních, formulovat své vlastní názory a být schopen je obhájit. Navyká studenta veřejně vystupovat, hodnotit ostatní i sám sebe. V neposlední řadě je nutno se také zamyslet nad tím, jakou roli zaujímá v diskuzi vyučující. Učitel ve funkci průvodce pouze řídí diskuzi, navozuje vhodnou atmosféru pro diskutující, snaží se, aby se debata věnovala hlavnímu problému, aby argumentace byla věcná, a zajištuje, aby se debaty účastnili všichni aktéři, tj. aby každý student bez obav sdělil svůj názor. V závěru vyučující shrne diskuzi, vysvětlí nesprávné názory či omyly, zdůrazní výsledky a konečná řešení, k nimž se dospělo.

Velmi často jsou projekty rovněž řešeny distančně. Distanční vzdělávání lze považovat za formu řízeného studia, kdy student není v př́mém kontaktu s vyučujícím nebo pod jeho stálým dohledem, využívá však předem stanovený plán a konzultace s tutorem (Rohlíková - Vejvodová 2012, 151), důraz je tedy kladen na autonomii učícího se subjektu, který sám určuje své studijní tempo, avšak musí splnit předem stanovené termíny daných úkolů. Distanční vzdělávání splňuje princip sebevzdělávání, kdy učící se subjekt dle vlastní volby určuje, kdy a kde bude co studovat, v popředí tedy stojí jeho samostatnost. Rovněž je naplněn princip individualizace, student má své vlastní tempo, svůj plán studia a možnost komunikovat s učitelem či spolužáky. Princip interaktivity spočívá v menších dávkách studia/dílčích úkolech a ve skutečnosti, že student dostává okamžitou individuální zpětnou vazbu. V distanční výuce lze také využít multimédia, což zprostředkovává efektní komunikaci (existují však i jistá úskalí, o nichž pohovoříme dále) a lze využít různé způsoby a prostředky prezentace učiva (Rohlíková - Vejvodová 2012, 152).

\section{Popis projektu}

Předpokladem pro účast $\mathrm{v}$ projektu byl zájem o překlad literárního díla a rovněž zájem vyzkoušet si práci na reálné překladatelské zakázce a týmový překlad včetně redakčních úprav; do projektu se zapojili studenti bakalářského i magisterského studia pod vedením dvou vyučujících. 
Následující schéma zachycuje průběh celého půlročního překladatelského projektu:

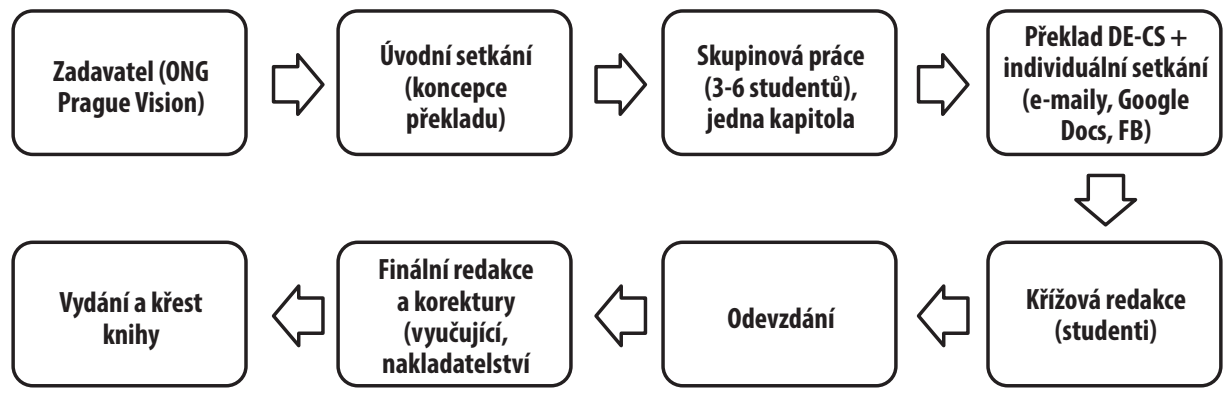

Schéma č. 1: Průběh př̀kladatelského projektu

Na úvodní hodině (leden 2019) byl studentům popsán celý projekt, včetně připravované konference věnované autorce knihy Bertě von Suttner, na níž měl být nový překlad představen a pokřtěn. Poté byl stanoven časový plán překladatelských prací i následné redakce, vyřešily se organizační záležitosti (např̀. studentská odměna v podobě kreditů), studenti se rozdělili do pracovních skupin. V našem projektu se uplatnilo především hledisko sociálních vztahů (skupiny, trojice až šestice, byly sestavené z přátel) a také výkonu (studenti téhož ročníku z bakalářského programu vs. magisterského programu, šlo tedy o homogenní skupiny sdružující studenty podobných znalostí a schopností), částečně také hledisko zájmu (studenti si zvolili kapitolu, která je zajímala, např. obsahovala překlad básně, prvky milostného románu či převody výňatků $\mathrm{z}$ dobového tisku). $\mathrm{V}$ pracovních týmech tak distančně řešili projektové úkoly a všichni se společně zamýšleli nad koncepcí překladu a možnými úskalími v celém díle. Snažili jsme se všechna zásadní rozhodnutí učinit již na tomto úvodním setkání, aby byla jednotná ve všech kapitolách; $\mathrm{k}$ několika posledním závazným změnám došlo těsně před redakcí textu.

Účastníci projektu během celého semestru průběžně konzultovali mezi sebou i s vyučujícími, a to jednak osobně, jednak pomocí online sdílených dokumentů, kam posléze nahrávali i hotové překlady jednotlivých kapitol a prováděli kř́žovou finální redakci textu. Obě vyučující tak vystupovaly v roli facilitátora, studenti samostatně plnili autentické úkoly a pracovali v reálném kontextu. Bylo využito kooperativního učení, nebot sdílení, spolupráce a vzájemná podpora doprovázely vlastní překladatelskou práci po celou dobu konání projektu.

Každý týden se vedoucí projektu sešly s jedním překladatelským týmem a detailně s ním probíraly problematické pasáže dané kapitoly; po těchto „individuálních“ konzultacích proběhlo ještě jedno setkání všech překladatelů, po němž následovala studentská redakce textu a vyhotovení finální verze. Během skupinových diskuzí nad přeloženým textem byl důraz kladen především na analýzu překladu, bylo třeba posoudit překlady vyhotovené $\mathrm{v}$ týmu, prodiskutovat rozdíly ve výběru jazykových prostředků, opravit pravopisné či gramatické nedostatky, poukázat na př́ípadné sémantické posuny (čímž bylo ověřováno správné porozumění textu). Následná skupinová diskuze vykazovala mnohé prvky konstruktivismu, nebơ při ní studenti rozvíjeli své komunikační dovednosti, kon- 
frontovali své názory se stanovisky druhých, a navíc měli možnost hodnotit sebe sama a srovnávat se s ostatními.

Překladatelský seminář vedený formou projektové výuky umožňuje studentům získat praktické zkušenosti na základě reálné překladatelské zakázky se zcela konkrétními podmínkami, jako je zadání př̀kladu, termín odevzdání atd., a došlo tedy k ideálnímu propojení akademického prostředí s překladatelským trhem.

\section{Vybrané překladatelské problémy}

Členové překladatelského týmu se museli vzájemně zkoordinovat, a to jednak z hlediska dodržování termínů odevzdání jednotlivých částí, aby je mohla číst a redigovat zase jiná skupinka studentů, jednak z hlediska jednotnosti celkové koncepce i dílčích strategií, jak který překladatelský problém vyřešit. Studenti se tak museli dohodnout na řešení překladatelských problémů na více rovinách.

Jedním ze zásadních úskalí při překladu byl faktor času v kombinaci se stylovou charakteristikou díla. Styl, kterým je román napsán, lze označit jako nadnesený až patetický: hlavní hrdinka Marta vypráví o prožitých válečných událostech a ztrátách velmi emotivně, až agitačně - snaží se tak čtenáři vštípit odmítavý postoj k válečným konfliktům, a naopak ho přesvědčit o přínosu myšlenky šíření míru. I nový český překlad měl mít takový ráz, avšak neměl využívat archaického nebo zastarávajícího jazyka, naopak měl dílo čtenáři přiblížit jazykem co nejpřirozenějším, nejsoučasnějším. Jak uvádějí sami překladatelé: „Tuto jedinečnou směs se překlad snaží zachovat - ponechat románu nadnesenost a citovost, zároveň předat jeho poselství srozumitelným jazykem a vyvarovat se nebezpečí př́lišného archaizování." (Čapková - Kučerová - Matoušová in von Suttner 2019, 18).

Pro lepší představu nabízíme srovnání dvou vybraných pasáží původního a nového českého překladu, které ilustrují výše popsanou překladatelskou metodu. V ukázce se projeví hned několik aspektů týkajících se archaického jazyka, s nimiž studenti museli vědomě pracovat - jedná se o otázku, zda využívat infinitivů na -ti (překladatelský tým se rozhodl s nimi nepracovat a využít neutrálních tvarů na $-t$ ), dále o využití neutrálních finitních slovesných tvarů (je, nikoli archaické jest), totéž se týká i dalších lexémů (čtrnácte - čtrnáct, radost nad životem - radost ze života). Patrný je i rozdíl v syntaktické stavbě věty, o které se zmíníme níže.

Originál je nápadný také po syntaktické stránce: bohatá souvětí jsou plná vložených vět, vsuvek a zvolání. Studenti takové konstrukce často museli zlogičtit a kvůli srozumitelnosti rozdělit do více jednoduchých vět. Hojná, velmi často až nadměrná interpunkce (především pomlčky, středníky a tři tečky na konci celých pasáží i jednotlivých vět) byla také zredukována, aby nerušila při plynulém čtení.

Autorka románu využívá několika vrstev lexika: vedle terminologie (především vojenské), kterou překladatelé konzultovali s odborníky na danou oblast, se v románu hojně vyskytují cizí slova, dokonce celé pasáže v cizích jazycích, zejména ve francouzštině, ale i v angličtině. Studenti cizojazyčnost kvưli zachování autenticity v textu ponechávali, avšak uvedli zároveň i překlad do češtiny, nebot’ u současného českého čtenáře už nelze znalost francouzštiny automaticky předpokládat. V originále se také 


\begin{tabular}{|c|c|}
\hline Berta ze Suttnerů: Odzbrojte! (1896) & Bertha von Suttner: Složte zbraně! (2019) \\
\hline $\begin{array}{l}\text { I tato sličnost, o kteréž moje zrcadlo nemůže } \\
\text { více mnoho tvrditi, jest mi starými podobiznami } \\
\text { zaručena. Mohu se domysliti, jakým as záviděním } \\
\text { tvorem mladistvá, jako kráska slavená vším možným } \\
\text { přepychem obklopená komtesa Marta Althausova } \\
\text { bývala. } \\
\text { (Kniha prvá 1859) }\end{array}$ & $\begin{array}{l}\text { Ano, také krásu, kterou si mé zrcadlo } \\
\text { vybavuje už jen matně, mi dnes připomínají } \\
\text { jen staré portréty. Umím si představit tu } \\
\text { záviděníhodnou, mladičkou, luxusem } \\
\text { obklopenou komtesu Martu Althausovou, } \\
\text { již každý obdivoval pro její krásu. } \\
\text { (Kniha první 1859) }\end{array}$ \\
\hline $\begin{array}{l}\text { Pozdrželi jsme se ještě čtrnácte dnů ve Vídni. Ta } \\
\text { dovolená nebyla ale nikteraž pro mne veselou dobou. } \\
\text { Tato „nemilá vyhlídka na válku“, o níž mluvilo se } \\
\text { ve všech časopisech a která ovládla všecky hovory, } \\
\text { připravovala mne o všecku radost nad životem. } \\
\text { (Kniha třetí 1864) }\end{array}$ & $\begin{array}{l}\text { Ve Vídni jsme zůstali ještě čtrnáct dní. } \\
\text { V tom prázdninovém čase mne ale nic } \\
\text { netěšilo. Ono osudné „,válka na dohled“, } \\
\text { o čemž se psalo a mluvilo úplně všude, mi } \\
\text { bralo jakoukoli radost ze života. } \\
\text { (Kniha třetí 1864) }\end{array}$ \\
\hline
\end{tabular}

Tabulka č. 1: Srovnání dvou českých překladů

setkáme s mnohými expresivními výrazy spojenými s líčením utrpení vojáků a jejich rodinných př́slušníků čekajících na zprávu o jejich návratu nebo smrti. Text je prodchnut také dobovými reáliemi, studenti tedy strávili mnoho času rešeršemi a dohledáváním vhodných ekvivalentů, museli adekvátně převést toponyma a propria - tehdy se nabízela především otázka, zda využívat český, nebo německý pravopis, zda ženská př́ijmení přechylovat, nebo ne. Pokud to bylo možné, pro místní jména bylo využito českého označení (vesnice Hořiněves, Světí, Hrádek atd.), případně vnitřní vysvětlivky. Křestní jména překladatelé přepisovali českým pravopisem (tedy Marta a Fridrich, nikoli Martha a Friedrich), příjmení ponechávali dle německého úzu, mezi postavami nalezneme tedy doktora Naundorffa nebo doktora Bressera (výjimku tvořil pouze generál Radecký, jehož jméno je u nás známé v této počeštělé podobě). Ženská přímmení se přechylovala pouze tehdy, nejednalo-li se o šlechtický titul, v knize tedy vystupuje na jedné straně komtesa Pálffy nebo zmiňovaná hlavní postava baronka Marta von Tilling společně s Lori Griesbachovou nebo s paní Simonovou.

Zásadní byla otázka, zda nově přeložit název díla či ponechat titul (srov. Levý 1998, 153-160) uvedený u prvního překladu z roku 1896. Ten zněl Odzbrojte!, anglický př̀klad (již z roku 1892) nese název Lay Down Your Arms!, podobně strukturovaného spojení využívají i tituly v dalších jazycích. Náš překladatelský tým se také rozhodl pro změnu původního titulu, román nyní nese název Složte zbraně!

\section{Dotazníkové šetření a hodnocení projektu}

Mezi účastníky projektu Bertha von Suttner: Die Waffen nieder! jsme provedli dotazníkové šetření, abychom zjistili, jakým způsobem vnímá projektovou výuku sám student budoucí profesionální př̀ekladatel. Oslovili jsme prostřednictvím e-mailu všech 19 studentů, vrátilo se nám celkem 8 odpovědí (respondenty označujeme S01-S08). Dotazník sestával z následujících dvanácti otevřených otázek: 
1. V čem se práce na překladu knihy Die Waffen nieder! lišila od tradiční výuky překladatelských seminářů? V čem jste spatřovali pozitiva? V čem negativa?

2. Vyhovovala vám flexibilní distanční forma studia a několik společných konzultací s vyučujícími?

3. Jak probíhal překlad jednotlivých kapitol (jak jste si rozdělili práce v týmu)?

4. Jak probíhala redakce jednotlivých kapitol (jak jste si rozdělili práce v týmu)?

5. Probíhala nějaká komunikace mezi všemi členy překladatelských týmů? Jakým způsobem?

6. Jaké největší překladatelské oříšky jste museli řešit? Jaká řešení jste zvolili a proč?

7. Konzultovali jste některé problémy s externími odborníky? Jaké to byly problémy a s kým jste konzultovali?

8. Tvưrčí práce s jazykem tvořila velkou část prací na překladu. Byla to pro vás příjemná změna oproti překládání sevřenějších forem textů, nebo jste se cítili spíše zaskočeni?

9. Co vás motivovalo $\mathrm{k}$ účasti na tomto semináři? (Kredity, publikovaný překlad, týmový překlad, jiná formy výuky překladu atd.)

10. Ocenili byste více takovýchto projektů během studia (tedy seminářů, kde se realizuje skutečná př̀kladatelská zakázka)?

11. Semináře se účastnili studenti bakalářského i magisterského studia. Mělo to podle vás nějaký vliv na práci na překladu a redakci?

12. Máte dojem, že vás zkušenost s prací na překladu a redakci této knihy obohatila, posunula dál? Nebo naopak vám nic nepřinesla?

Co se týče reakcí na první otázku, studenti spatřovali v projektové výuce hned několik odlišností od tradičního způsobu vedení překladatelských seminářù, např. se „[1]išila týmovou prací a absencí prezenčních seminářů, byla také orientovaná čistě prakticky. Vyzkoušeli jsme si i redakci.“ (S2) Asi největší rozdíl spočíval v tom, že „jsme překládali každý něco jiného, ne stejný text, jako to bývá na seminářích. Sice jsme tak nemohli porovnávat vzájemně svá řešení, ale ke konzultacím svých překladů jsme měli jiné možnosti, především v rámci skupiny pracující na jedné kapitole a pak v rámci redakce." (S03) Další znatelný rozdíl je chronologického rázu, tj. kdy se diskutuje o možných překladatelských řešeních a problémech: „Na klasických překladatelských seminářích se debatuje o již udělaném překladu a komentují se jednotlivé verze. Tady jsme spíš předjímali, co by mohlo být problematické, abychom pro to našli společná řešení.“ (S04) Kromě ryze didaktických aspektů či pozitiv studenti poukázali i na hledisko sociálních vztahů: „Vím, že následující důvod je spíše vedlejší, ale pro mě také důležitý - velmi se utužily vztahy mezi spolužáky. O volných hodinách jsme seděli spolu a diskutovali o překladu." (S08)

Nicméně největší př́ínos spatřují studenti ve skutečnosti, že si vyzkoušeli reálnou překladatelskou zakázku, což bylo patrné $\mathrm{v}$ jejich př́stupu $\mathrm{k}$ textu překladu i v celkovém nasazení: „V tomto semináŕi jsem měla poprvé pocit, že dělám nějakou smysluplnou překladatelskou práci. Na překladu jsem si dala mnohem více záležet než na překladech, které končily v šuplíku.“ (S08) Skutečnost, že výuka neprobíhala prezenční formou, dala studentům „větší míru volnosti a zároveň zodpovědnosti“ (S06), „museli prokázat mnoho sebedisciplíny [...] a k dodržování termínů [je] tlačila i zodpovědnost vůči zbytku týmu. “(S03) Někteří díky účasti na překladu knihy Die Waffen nieder! zřejmě našli svou budoucí specializaci: „Na tomto projektu jsem spatřovala jen pozitiva - zjistila jsem, že mě literární překlad opravdu baví." (S08) 
Jisté úskalí týmového překladu studenti spatřovali v rozkolísanosti stylu, udržení jednotného překladu konkrétních výrazů a v odsouhlasení společného postupu, jak ilustruje výpověd’ jednoho z respondentů: „Naopak negativem podle mě bylo, že nás na překladu pracovalo opravdu hodně a bylo tedy těžké text ,sladit', domlouvat se na jednotlivých věcech“ (S06); na druhou stranu, „více lidí více vymyslí.“ (S04) Jednotný styl celého textu nakonec zajistila finální korektura ze strany obou vedoucích projektu a redaktorky nakladatelství.

Flexibilní distanční forma semináře byla již zhodnocena jako pozitivum, takže na druhou otázku logicky všichni dotazovaní odpověděli kladně: „Ano - nechalo nám to prostor si práci sami rozvrhnout, ale zároveň konzultace zajistily, že jsme si práci nenechali na poslední chvíli." (S01) Další respondent ještě dodává, že studenti ocenili setkání s vyučujícími, při nichž měli př́ležitost „si ujasnit mnohé problémy“. (S06)

Jak probíhal celý projekt, jsme již popsali výše (tj. každá skupina měla vždy za úkol přeložit jednu kapitolu, za jejíz finální podobu byla zodpovědná), zde jen upřesníme, jak probíhala práce na překladu v rámci daného překladatelského týmu:

Každý kapitolu přečetl a poté jsme ji rozdělili na základě počtu stran a také logických úseků. Každý dostal možnost vybrat si část, která mu byla sympatická, a stanovili jsme si datum setkání pro domluvení společného postupu a vyřešení problémů. Komunikovali jsme prostřednictvím společné konverzace na Facebooku, kde jsme probírali i problematická místa. (S04)

Poté, co každý student vypracoval překlad své přidělené části, snažili se studenti sjednotit styl v rámci své kapitoly, takže si navzájem své př̌klady přečetli, vyřrešili př́ípadné nejasnosti a vyhotovili konečnou verzi, již předložili k redakci. Pokud během práce na překladu překladatelé nemohli pro danou pasáž najít vhodné řešení, konzultovali s dalšími kolegy př́mo ze svého týmu, či dokonce z týmu, jenž měl na starosti jinou kapitolu, protože věděli, kdo které části překládá (S01). Některé týmy si smluvily schůzku několik týdnů před odevzdáním textu $\mathrm{k}$ redakci, před ní si poslaly své ještě nehotové překlady $s$ vyznačenými problémy, které si vzájemně okomentovaly a zbytek probraly osobně na schůzce (S03).

Nicméně respondent S07 poukázal na fakt, že na překladu básně se nepodílela jen jejich skupina, ale celý překladatelský tým, tj. všichni účastníci projektu: „Báseň v naší kapitole jsme překládali společně (přidali se myslím i lidé z jiných kapitol), do výsledné podoby byly zakomponovány části veršů od všech přispěvatelů."

Studenti-redaktoři se shodují, že rozdělení práce při redakci jednotlivých kapitol probíhalo obdobně jako u překladu, tj. podle počtu stránek, které si spravedlivě rozdělili, takže každý četl svůj úsek. Na tomto místě je třeba podotknout, že některé týmy zkontrolovaly pouze svou přidělenou část (většina dotazovaných), nicméně některé skupiny nakonec prošly i zbylou část kapitoly, avšak nikoli tak podrobně (S02, S06). Veškeré své postřehy, změny a komentáŕe zanášeli studenti prímo do sdíleného dokumentu.

Mezi všemi členy překladatelských týmů probíhala komunikace především prostř̌ednictvím hromadných e-mailů, na facebookové skupině založené pro účely projektu, na skupinových setkáních i s vyučujícími či prostřednictvím osobních schůzek v prostorách fakulty. Překladatelé se kontaktovali hlavně v př́padech, když se objevily problematické 
výrazy či spojení, která se navíc opakovala ve více kapitolách. Někteří respondenti přiznávají, že e-mailová komunikace nebyla moc efektivní: „Iritovalo mě, že jsem se opakovaně snažila komunikovat ohledně ministra Allerdings a výrazu Edelmensch, nikdo se mi ale dlouho neozýval, teprve před závěrečným odevzdáváním se to začalo trochu řešit, ale nijak koncepčně.“ (S02) „Pasivni“" komunikace také probíhala prostřednictvím sdíleného glosáře vojenské terminologie, toponym, proprií či chrématonym; díky tomuto závaznému seznamu německých termínů a jejich českých ekvivalentů měla být zajištěna jednotnost $\mathrm{v}$ rámci celé knihy. Respondent $\mathrm{S} 03$ přichází se zlepšujícím návrhem, a to v podobě zápisu z každého setkání: „Př́iště by se měl dělat zápis (mám dojem, že se jinak dělal jen na jedné schůzce) a měly by se strukturovaněji probírat problémy, které by si všichni předtím pročetli a měli k nim smysluplné poznámky.“

Následující řádky se věnují překladatelským „oříškủm“, které museli studenti vyřešit. Na některé překladatelské obtíže jsme již upozornili výše, zde pro ilustraci nabízíme další lexikální problémy:

Konkrétně například slovo „Schlachtfeld“, kdy autorka využívala mnohoznačnosti slova. Řešila jsem slovem „porážka“ a mírně upravila kontext, aby zůstal význam celého odstavce zachován. Dále veškerá vlastní jména v textu - potřeba přistupovat individuálně, někdy zachovat, jindy přeložit. Občasné narážky na reálie. $V$ tomto př́ípadě šlo spí̌se o ověřování dat, jmen osobností apod. Poslední věcí, která mě nyní napadá, jsou určité specifické výrazy jako „niedergezischt“. V takových př́ípadech jsem konzultovala s rodilými mluvčími a řešila podle celého kontextu. U slova „niedergezischt“ jsem volila „smést pod stůl“. (S05)

Z jazykového hlediska byly obtížné zvláštní výrazy, které si němčina mohla dovolit používat na více místech, na rozdíl od češtiny. Např. obtížně přeložitelný výraz „kannegießen, Kannegießerei“, nebo „Partie“ ve smyslu jak hry, tak válečného střetu. V takových př́padech bylo nutné smíriti se s užitím různých slov či opisu. Dále bylo obtí̌né se popasovat se složitými větami a celkově stavbou textu tak, aby to pro českého čtenáře bylo srozumitelné. $\mathrm{V}$ takových př́ípadech bylo možné věty rozdělovat a člověk se musel odpoutat od př́lišného lpění na stavbě německého souvětí. (S03)

Vidíme, že respondent $\mathrm{S} 03$ upozorňuje ke konci své výpovědi na komplikovanou syntax (tu ostatně zmiňují i ostatní studenti) a dlouhá, rozsáhlá, těžko rozklíčovatelná souvětí, protože u několikanásobných souvětí vztažných studenti často nechápali, ke které části se která věta vztahuje, takže bylo těžké mu porozumět (S08). Porozumění navíc komplikovala špatná technická stránka originálu: „Pro mě byla největší výzvou syntax (někdy v kombinaci s chybějící interpunkcí ve výchozím textu). Snažila jsem se, aby byla i v češtině složitá, ale zase ne až tolik jako v němčině, někde jsem intelektualizovala, protože by mi text jinak přišel stěží pochopitelný." (S02) Obtížné bylo rovněž zachování patetického stylu (S02, S03, S04), nebot zároveň bylo nutné se vyvarovat archaizování (S03). Další výzvou bylo převést text do současného jazyka (S04). Pokud se v textu vyskytl třetí jazyk, v našem př́padě především francouzština, konzultovali studenti se svými kolegy francouzštináři. Novou zkušeností byl také překlad básně (S01, S07), na němž, jak už jsme uvedli, se podílely všechny překladatelské týmy společně. Hlavní hrdinka, respektive autorka knihy často uvádí nepravdivé prameny, takže studenti museli provést důkladnou rešerši, ověřit si dané informace a rozhodnout, zda chybu v překladu opraví, či nikoli. Důkladné dohledávání některých archaických či knižních výrazů připomínalo „detektivní pátrání: 
Dále byl opravdu velký problém překládat slova, která jsem nemohla nikde najít. Nejdřív jsem slovo zadala do normálního slovníku, poté do DWDS a když jsem nic nenašla, zadala jsem slovo v uvozovkách do vyhledávače. Jediný výskyt byl v knize Die Waffen nieder!. S tímto se pak pracuje opravdu špatně. (S08)

Jelikož je originální text bohatý na vojenskou terminologii i pasáže ve francouzštině, zajímalo nás, zda studenti konzultovali s odborníky na danou problematiku. Respondenti uvedli, že tomu tak bylo, avšak pouze u některých kapitol: „Vojenskou terminologii jsme konzultovali s odborníkem z Vojenského historického ústavu." (S03) S francouzskými výrazy a citáty pomohli také kolegové francouzštináři. (S02)

Tvưrčí práce $s$ jazykem všechny řešitele projektu bez výjimky bavila a takový překlad považovali za př́jemnou změnu (S02), prrípadně to byl aspekt, který je na projektu bavil nejvíce (S03), i když jej někdy považovali za výzvu, která je zaskočila (S04, S08). Respondent S07 z hlediska kreativity hodnotí také to, že každá postava mluví jiným jazykem, což se v přkekladu samozřejmě také musí projevit.

Motivace vedoucí studenty $\mathrm{k}$ účasti $\mathrm{v}$ tomto projektu spočívala především $\mathrm{v}$ tom, že měli „příležitost podílet se na skutečném překladu“ (S06), př́ípadně na překladu celé knihy (S03, S05). Jak uvádí S02, důvodem k účasti v tomto projektu byl i podíl na smysluplné osvětové činnosti. Studentské kredity, které účastníci za projekt dostali, pro ně rozhodující nebyly, jak uvádějí explicitně např. studenti S06 nebo S07. Posledně uvedený respondent shrnuje své stanovisko následujícím způsobem:

Kredity vůbec, těch mám až moc. Publikovaný překlad ano, ale nebyl to primární zdroj motivace. Byla jím asi hlavně zkušenost s překladem knihy - je dobré si to zkusit „nanečisto“, než člověk přijde někam do nakladatelství a podepíše smlouvu. Zjistí tak, jestli by pro něj takový typ práce byl zajímavý. (S07)

V̌̌ichni studenti se jednomyslně shodli na tom, že by rozhodně uvítali více projektů představujících reálnou překladatelskou zakázku a doufají, že v budoucnu jim budou podobné překlady opět nabízeny. Zároveň si však uvědomují, že vést takový seminář není jednoduché: „Rozhodně. (Uvědomuji si však, že zorganizovat takovýto projekt je náročné.)“ (S04)

Protože byl seminář určen studentům bakalářského i magisterského studia, měli řešitelé příležitost seznámit se se studenty z jiných ročníků nebo oborových kombinací. To bylo možné především na společných schůzkách a při komunikaci online, protože jednotlivé pracovní skupiny byly složené bud' z bakalářských, nebo magisterských studentů. Podle názoru studentů nešlo o nevýhodu, spíše to podněcovalo kooperaci a zvyšovalo pocit odpovědnosti. Na otázku, zda měla tato spolupráce mezi dvěma stupni studia na práci nějaký vliv, odpověděli většinou, že ne, případně jen velmi omezený. Následuje odpověd' magisterského studenta:

Možná pouze do té míry, že mladší studenti si ještě tak nevěřili a potřebovali konzultovat více problémů. Musím se přiznat, že v případě redakce jsem se někdy obávala, jestli mladší studenti odhalí všechny nedostatky. Ujištovalo mě ale vědomí, že to po nás budou číst ještě i vyučující, což rozhodně bylo potřeba. V naší skupině jsme se všichni znali a byli jsme téměř všichni na magisterském stupni, takže jsem rozdíly nepocitovala. (S04) 
Studenti bakalářského programu si uvědomovali, že musí vynaložit zvýšené úsilí, aby jejich řešení byla přijata, opět ale negativní vliv na práci celkově nepocitovali:

Myslím, že ne, přišlo mi, že studenti z nižších ročníků byli ve větších skupinách, příp. dostali méně stránek. Redakce od zkušenějších pak pomohla zahladit nějaké nerovnosti. Všichni podle mě vynaložili dost úsilí. (S06)

Studentské komentáře k poslední otázce, a sice zda je práce na tomto překladu obohatila, svědčí, že tomu tak bez výjimky bylo. Váží si zejména možnosti překládat skutečnou knihu, zmiňují také zkušenosti získané díky týmovému překladu (S01), ale i prohloubení jazykových znalostí (S06). Odpovědi poukázaly také na skutečnost, že si studenti uvědomují, jak zásadním aspektem je redakce textu (S01, S02). Rovněž zmiňují pozitivum v podobě vytvoření určité hodnoty (S03). Jako shrnutí zde uved’me komentár jedné $\mathrm{z}$ účastnic, který zmiňuje ty nejdůležitější faktory překladatelského semináře:

Ano. Zjistila jsem, že dokážu překládat i krásnou literaturu, i když v hodinách jsme dělali spíš texty jiného typu. Také jsme si uvědomila, o kolik jsem se v rámci studia posunula a jaký pokrok jsem udělala od prvních překladů v prvním ročníku. Vždy potěšilo, když redaktor k odstavci neměl komentáře. Př́nosná byla určitě i spolupráce na kapitolách a později redakci, protože i to nás jako budoucí překladatele čeká. Opět jsme si uvědomila, kolik chyb a nejasností nejsem schopna zaznamenat sama a jak moc všichni potřebujeme dobrého redaktora. (S04)

\section{Závěr}

Záměrem našeho článku bylo představit možnosti projektové výuky v překladatelských seminářích určených oborovým studentům. Východiskem pro naše uvažování byl funkcionalistický př́istup, na základě kterého fungují překladatelské projekty jako reálné zakázky, jež je nutné realizovat za zcela konkrétních podmínek včetně zadání překladu, termínu odevzdání apod. (Mraček 2012). Pokud jde o skutečnou překladatelskou zakázku, nikoli fiktivní zadání, je překladatelský projekt ještě přínosnější. Provedené dotazníkové šetření poukazuje na skutečnost, že projektová výuka a kooperativní učení (srov. Kasíková 1997) studentům přináší praktické zkušenosti a dovednosti, co se týče jednak řešení skutečného překladatelského úkolu, jednak práce v týmu. Lze pak uvažovat o prrínosu na rovině intelektuální i sociální - kromě obohacení a prohloubení vlastních znalostí dochází k interakci a prohlubování sociálních vztahů nejen s učitelem, ale i s ostatními studenty.

Nicméně je nutné na tomto místě ještě vyzdvihnout pozitiva a upozornit na negativa překladatelských projektů. Překladatelský projekt ve formě reálné překladatelské zakázky zprostředkovává studentům, budoucím profesionálním překladatelům, kontakt s překladatelským trhem, př́ípadně je učí práci v týmu. Projekty bývají vedené distanční formou výuky, případně prostřednictvím e-learningu, což vede studenty k samostatnosti, zodpovědnosti a time managementu. V neposlední řadě si studenti mohou osvojit nové dovednosti, $v$ našem př́padně redakci a korekturu textu; což jsou činnosti, na něž nebývá při klasické výuce dostatek prostoru. S výukou na dálku je spojené i jedno z negativ, a to 
je ne př́liš flexibilní komunikace, která může mít za následek zpomalení celého procesu. Pokud jde o vedoucí projektu (vyučující), je pro ně výuka touto formou časově a organizačně velmi náročná. $\mathrm{V}$ neposlední řadě lze jako nevýhodu vnímat i žánr překládaného textu. Překlad literárních textů je jednou z nejnáročněǰích disciplín, nebot literární dílo je vždy součástí určitého sociokulturního a literárního polysystému. Rozhodneme-li se jej přeložit, nejde o pouhý převod do jiného jazyka, ale o přenesení textu do jiného polysystému, přičemž musí překladatel zohlednit určitá pravidla a omezení.

I přes jisté nedostatky se však domníváme, že pokud bude v překladatelských seminářích využíváno projektové výuky, lze očekávat, že si studenti osvojí dovednosti potřebné pro tvůrčí práci s jazykem, zdokonalí si během diskuzí své komunikační a argumentační schopnosti a naučí se pracovat $\mathrm{v}$ týmu. Všechny tyto nabyté zkušenosti, schopnosti a dovednosti podle našeho názoru vedou zásadním způsobem $\mathrm{k}$ adekvátní př́ípravě na budoucí překladatelskou profesi.

\section{BIBLIOGRAFIE}

Bertha von Suttner: 130 let myšlenek, které nestárnou. Dostupné z: https://bertha.praguevision.org/cs/ [4. 8. 2020].

Čapková, Andrea - Kučerová, Kristina - Matoušová, Tereza: Složte zbraně! očima překladatelského týmu, in: Bertha von Suttner: Složte zbraně! Praha: Prosvěta 2019, s. 17-20.

Kasíková, Hana: Kooperativní učení, kooperativní škola, Praha: Portál 1997.

Levý, Jiří: Umění prekladu, Praha: Ivo Železný 1963/1998.

Mraček, David: Translation as a Modern Tool for Language Teaching, in: ed. Ilona Semrádová: Intercultural Inspirations for Language Education: Spaces for Understanding, Hradec Králové: M\&V 2012, s. 64-73.

Mračková Vavroušová, Petra - Kloudová, Věra: Překladatelský projekt „Bertha von Suttner: Die Waffen nieder!“, in: Bertha von Suttner: Složte zbraně! Praha: Prosvěta 2019, s. 13-15.

Mračková Vavroušová, Petra: Projektová výuka v překladu, in: ed. Eva Hrdinová a kol.: Překlad jako didaktický nástroj ve výuce jazyků, Olomouc: Univerzita Palackého v Olomouci 2018, s. 117-126.

PragueVision - Institut pro udržitelnou bezpečnost. Dostupné z: https://www.praguevision.org/cs/ [4. 8. 2020].

Rohlíková, Lucie - Vejvodová, Jana: Vyučovací metody na vysoké škole, Praha: Grada 2012.

Skalková, Jarmila: Obecná didaktika, Praha: Grada Publishing 1999, 2007.

Suttner von, Bertha: Složte zbraně! Praha: Prosvěta 2019.

Suttner von, Bertha: Die Waffen nieder! Wien: EAS, Editionartscience 1889/2010.

Suttnerů ze, Berta: Odzbrojte! V Praze: Tiskem a nákladem Edvarda Beauforta 1896.

\section{RESÜMEE}

Die Ausbildung von Übersetzern vertraut vermehrt auf Simulationen der realen Berufspraxis. Eine Möglichkeit, das Lernen und die authentische Berufspraxis näher zu verknüpfen ist die Einführung von projektbezogenem Unterricht. Ziel dieses Beitrags ist die Vorstellung eines Projektes, das im Sommersemester des akademischen Jahres 2018/2019 im Rahmen eines fakultativen Seminars zur Literaturübersetzung am Institut für Translatologie der Philosophischen Fakultät der Karls-Universität (Prag) durchgeführt wurde. Das Projekt war eine Gemeinschaftsübersetzung des Buches Die Waffen nieder! von Bertha von Suttner aus dem Deutschen ins Tschechische unter der Leitung von zwei tschechischen 
Dozierenden, um den Studierenden die Möglichkeit eines authentischen Übersetzungsauftrags zu bieten. Während der Eröffnungssitzung wurde ein Arbeitsplan erstellt, der alle Phasen der Übersetzung und Bearbeitung berücksichtigte. Später arbeiteten die Studierenden in Gruppen an einzelnen Kapiteln und berieten sich mit den anderen Gruppen und Dozierenden, sowohl persönlich als auch über gemeinsame Online-Dokumente, in denen auch die Bearbeitung stattfand. Die Studierenden arbeiteten selbständig an authentischen Aufgaben in einem realen Kontext, mit den Dozierenden als Vermittler. Auf das Projekt wurde das Prinzip des kooperativen Lernens angewandt, da Teilen, Zusammenarbeit und gegenseitige Unterstützung Teile jeder Übersetzungsphase waren. Die Teilnehmer beantworteten einen Fragebogen, mit dem die Einstellungen und Gefühle der Lernenden in Hinblick auf projektbasiertes Lernen in der Übersetzerausbildung untersucht werden sollte, um die Möglichkeiten und Grenzen dieser Art des Lernens mit konventionellen Unterrichtsformen zu vergleichen. Die interessantesten Antworten der Studierenden werden im Schlussteil der Studie kommentiert.

Mgr. Vèra Kloudová, Ph.D.

Ústav translatologie, Filozofická fakulta, Univerzita Karlova

vera.kloudova@ff.cuni.cz

PhDr. Mgr. Petra Mračková Vavroušová, Ph.D.

Ústav translatologie, Filozofická fakulta, Univerzita Karlova

petra.mrackovavavrousova@ff.cuni.cz 